

\section{Daftar Isi (Table of Content) Journal of Government
Civil Society}

\begin{tabular}{|c|c|}
\hline \multirow{3}{*}{$145-158$} & $\begin{array}{l}\text { Political Law's Reconstruction of Village Apparatus to Realize Independent } \\
\text { Village in Indonesia }\end{array}$ \\
\hline & Hartati' ${ }^{1}$ Pahrudin HM$^{2}$, Elita Rahmi ${ }^{1}$ \\
\hline & $\begin{array}{l}\text { ('Faculty of Law, Universitas Jambi, Indonesia) } \\
\text { ('Departement of Government Science, STISIP Nurdin Hamzah Jambi, Indonesia) }\end{array}$ \\
\hline \multirow{3}{*}{$159-179$} & $\begin{array}{l}\text { Policy of a Merit System to Make a Good and Clean Government in The } \\
\text { Middle of Bureaucratic Politicization }\end{array}$ \\
\hline & $\begin{array}{l}\text { Yahya Pandega Putra1, 2, Eko Priyo Purnomo, }{ }^{1,} \text {, Suswanta Suswanta1, } \\
\text { Aulia Nur Kasiwi1, }\end{array}$ \\
\hline & $\begin{array}{l}\text { ('Jusuf Kalla School of Government, Universitas Muhammadiyah Yogyakarta, Indonesia) } \\
\text { ('Department of Government Affairs and Administration, Universitas Muhammadiyah } \\
\text { Yogyakarta, Indonesia) }\end{array}$ \\
\hline \multirow{3}{*}{$181-199$} & $\begin{array}{l}\text { Smart Human Security: Economic Safety for Micro, Small and Medium } \\
\text { Enterprises (MSMEs) to Face The Impact of The Covid-19 Global Pandemic }\end{array}$ \\
\hline & Elyta $^{1}$, Warjio ${ }^{2}$, Ahmad Azrin Bin Adnan ${ }^{3}$ \\
\hline & $\begin{array}{l}\text { ('Faculty of Social and Political Sciences, Universitas Tanjungpura, Indonesia) } \\
\text { ('Faculty of Social and Political Sciences, Universitas Sumatera Utara, Indonesia) } \\
\text { ( }{ }^{3} \text { Faculty of Business and Management, Universiti Sultan Zainal Abidin (UnisZa), } \\
\text { Trengganu, Malaysia) }\end{array}$ \\
\hline \multirow{3}{*}{$201-218$} & $\begin{array}{l}\text { Using The "Return on Investment" Strategy to Sustain Logistic Supply } \\
\text { Provider Toward Indonesia's Logistic Policy }\end{array}$ \\
\hline & Riska Rahayu ${ }^{1,2}$, Eko Priyo Purnomo, ${ }^{1}$, Ajree Ducol Malawani ${ }^{1,3}$ \\
\hline & $\begin{array}{l}\text { ('Jusuf Kalla School of Government, Universitas Muhammadiyah Yogyakarta, Indonesia) } \\
\text { ('Magister of Government and Public Affairs, Universitas Muhammadiyah Yogyakarta, } \\
\text { Indonesia) } \\
\text { ('Doctoral Program of Political Islam, Universitas Muhammadiyah Yogyakarta, Indonesia) }\end{array}$ \\
\hline \multirow{3}{*}{$219-228$} & $\begin{array}{l}\text { Indonesia Universal Health Coverage Implementation on University } \\
\text { Students }\end{array}$ \\
\hline & Adityo Pratikno Ramadhan ${ }^{1}$, Budiyono Budiyono ${ }^{1}$, Djonet Santoso ${ }^{1}$ \\
\hline & ('Sustainable Development Goals Center, Universitas Bengkulu, Indonesia) \\
\hline
\end{tabular}


The Local Government of Kulon Progo Regency Innovation in Subduing Capitalism through Community Empowerment

229 - 247 Muhammad Eko Atmojo ${ }^{1}$, Helen Dian Fridayani ${ }^{2}$

('Departement of Government Science, Universitas Muhammadiyah Yogyakarta, Indonesia)

('Departement of Political Science, National Cheng Kung University, Taiwan)

Land Administration Policy In Bantul and Sleman Districts

$249-272$

Subekti Widiyasno1, Dyah Mutiarin 1, Herdin Arie Saputra1, Ikhwan

Rahmatika Latif ${ }^{1}$

('Department of Government Affairs and Administration, Universitas Muhammadiyah Yogyakarta, Indonesia)

Increasing Local Own-Source Revenue through The Development of The Regional Tourism Sector

$273-291$

Harries Madiistriyatno', Ida Musdafia Ibrahim², Dudung Hadiwijaya ${ }^{3}$

('Program Studi Magister Manajemen Sekolah Tinggi Manajemen IMMI, Indonesia) (2Program Studi Manajemen Sekolah Tinggi Ilmu Ekonomi Y.A.I, Indonesia)

(3Program Studi Manajemen, Universitas Muhammadiyah Tangerang, Indonesia) 


\title{
Increasing Local Own-Source Revenue through The Development of The Regional Tourism Sector
}

\author{
Harries Madiistriyatno ${ }^{1 *}$, Ida Musdafia Ibrahim ${ }^{2}$, Dudung Hadiwijaya ${ }^{3}$ \\ ${ }^{1}$ Program Studi Magister Manajemen Sekolah Tinggi Manajemen IMMI, Indonesia \\ ${ }^{2}$ Program Studi Manajemen Sekolah Tinggi Ilmu Ekonomi Y.A.I, Indonesia \\ ${ }^{3}$ Program Studi Manajemen, Universitas Muhammadiyah Tangerang, Indonesia \\ *Email Correspondence: harries.madi@gmail.com
}

\begin{abstract}
The tourism sector is one important sector that can contribute to improving the regional economy. However, the implementation of product and tariff strategies that are not optimal can have an impact on the low sales value and profits, and in turn affect regional revenues. This study aims to analyze the effect of product strategy performance, tariff strategy and sales value on profits. Using a quantitative approach, the population in this study is 20 tourist destinations in DKI Jakarta Province. Primary data were obtained through questionnaires and interviews, while secondary data were obtained through documents and related literature. The data analysis technique used is path analysis. The results of this study indicate product strategy, tariffstrategy, and sales value have a partial and simultaneous effect both on profit. The dominant variables in this study are (1) the application of the tariff strategy as a determinant of sales value and (2) the application of the product strategy as a determinant of profit.
\end{abstract}

Keywords: Product strategy, tariffstrategy, DKI Jakarta tourism, Local Own-Source Revenue

\begin{abstract}
ABSTRAK
Sektor pariwisata merupakan salah satu sektor penting yang bisa berkontribusi bagi peningkatan perekonomian daerah. Namun demikian, penerapan strategi produk dan tarif yang tak maksimal dapat berdampak pada rendahnya nilai penjualan serta laba yang diperoleh, dan pada gilirannya memengaruhi penerimaan daerah. Penelitian ini bertujuan untuk menganalisis pengaruh kinerja strategi produk, strategi tarif dan nilai penjualan terhadap laba usaha. Menggunakan pendekatan kuantitatif, populasi dalam penelitian ini adalah 20 destinasi wisata di Propinsi DKI Jakarta. Data primer diperoleh melalui kuesioner dan wawancara, sementara data sekunder diperoleh melalui dokumen dan literatur-literatur terkait. Teknik analisis data yang digunakan adalah path analysis. Hasil penelitian ini menunjukkan strategi produk, strategi tarif, dan nilai penjualan berpengaruh secara simultan terhadap laba. Variabel dominan dalam penelitian ini ialah (1) penerapan strategi tarif sebagai determinan penjualan dan (2) penerapan strategi produk sebagai determinan laba.
\end{abstract}

Kata Kunci: Strategi produk, strategi tarif, pariwisata DKI Jakarta, pendapatan asli daerah (PAD)

\section{INTRODUCTION}

Tourism industry is an important sector that contributes to country's economic growth (Hieu \& Yen, 2019; Manzoor et al., 2019; Ohlan, 2017; Purwomarwanto \& Ramachandran, 2015; $\mathrm{Wu} \& \mathrm{Wu}, 2019)$. The tourism industry is also the largest foreign exchange contributor for developing countries like Indonesia (Antara \& Sumarniasih, 2017; Holik, 2016), and at the same time is able to boost the regional economic growth (Suhel \& Bashir,

Citation : Madiistriyatno, Harries, Ida Musdafia Ibrahim, and Dudung Hadiwijaya. 2020. "Increasing Local Own-Source Revenue through The Development of The Regional Tourism Sector." Journal of Government and Civil Society 4(2):273-291. 
2018). Through the development of tourism sector, job opportunities will be more widely opened, which in turn will increase income of local people (Annisarizki \& Sucahya, 2018; Anwar et al., 2017; Hakim, 2017; Isniati \& Yusrini, 2019; Rahma, 2020; Simamora \& Sinaga, 2016).

Tourism sector also contributes to increasing Local Own-Source Revenue (PAD), which comes from hotel taxes, restaurants, recreational site levies, and other sources (Astuti, 2019; Jaenuddin, 2019; Puspitasari et al., 2018; Soeswoyo, 2019; Wahyuni \& Utara, 2018). In fact, PAD in several regions has increased by implementing appropriate tourism programs while at the same time encouraging infrastructure development (Ratnawati, 2016; Reisha, 2019). This means that one of the efforts to increase PAD can be done by developing tourism, both existing tourist destinations and tourist destinations that want to be developed. In this case, local governments need to build synergistic cooperation with other stakeholders, especially with the surrounding community (Annisarizki \& Sucahya, 2018; Kurniawati et al., 2018; Simamora \& Sinaga, 2016; Singgalen et al., 2019).

As the capital city, the tourism sector has an important role in the formation of Gross Regional Domestic Product (GRDP) (Hakim, 2017). During 2003-2016, the contribution from tourism sector was recorded at an average of 4.96\%: 4.93\% in 2003-2009 and 4.99\% in 2012-2016. The tourism sector in DKI Jakarta also managed to grow by $5.80 \%$ in 2016 , higher than the growth of the national tourism sector (4.17\%) (Hakim, 2017). Therefore, tourism potential in DKI Jakarta can be developed so that its contribution to PAD increase and the impact can be felt by people (Simangunsong \& Tahir, 2018; Vieira et al., 2016).

The DKI Jakarta government is also working to increase PAD from the tourism sector. This can be seen in 2019 (January to February) where there was an increase of 22\% compared to the previous year. In January 2019, the revenue that went to the regional treasury was 485 billion and in February 2019 it was 537 billion. The increase was sourced from all PAD component sectors: hotel tax, entertainment tax and restaurant tax (AntaraNews, 2019). To maintain this positive trend, various strategic steps certainly need to be taken by local governments, such as holding various unique tourism programs (Kusuma, 2019; Pop et al., 2016; Rahayu, 2018), collaborate with communities (Kurniawati et al., 2018; Singgalen et al., 2019) or develop a marketing strategy that is both appropriate and effective (Alisher, 2017; Basera, 2018; Font \& McCabe, 2017; Nugraha et al., 2019).

From the strategic efforts that can be made by local governments, this research focuses on tourism marketing strategies, which are related to product strategies, price strategies, sales, and profits. The four concepts will be arranged in an influence model to examine the relationship or linkage between the product strategy and the tariff strategy $\left(\mathrm{H}_{1}\right)$ and how they influence sales value $\left(\mathrm{H}_{2}\right)$. These variables (product strategy, price strategy, and sales value) will be tested in relation to how they affect profit $\left(\mathrm{H}_{3}\right)$. 
This research is also based on several previous studies, especially research related to product strategy (Selnes, 1993), tariff strategy (Krishnamurthi \& Raj, 1991; Mulhern \& Leone, 1991), and also product and tariff strategies (Nyström et al., 1975; Reibstein \& Gatignon, 1984; van der Wiele et al., 2002; Walters, 1991). Meanwhile, the scope that distinguishes this research from these studies is the direction of the achievement of product strategy performance and tariff strategy on sales value as well as how the three influences the profit. In addition, the sector behind this research is the (regional) tourism sector and is related to the increase in PAD, while the previous studies described earlier were more aimed at the retail sector.

\section{METHODS}

This research is a quantitative research. Population in this study were 20 tourism service businesses in DKI Jakarta Province, consisting of two types of tourism: natural tourism and man-made tourism. The respondents involved in this study were 600 respondents with the same allocation: 30 respondents per tourism business. Distribution of samples for each tourism business is determined with the same allocation. The consideration of equal allocation is the high difference in the number of visits in each tourism business. If the allocation is carried out proportionally based on number of visits to each tourism business, majority of tourism businesses $(65 \%$ or 13 out of 20 tourism businesses) with a low number of visits are only represented by one person and this is considered to be less representative of the visitors it represents. Respondent characteristics chosen for each tourism business are those with highest frequency of visit by considering adjusting the differential advantage of each tourism business.

Table 1. Research Population

\begin{tabular}{ll}
\hline Types of Tourist Attractions & \multicolumn{1}{c}{ Tourist Attraction } \\
\hline Natural Tourism & (1) Pelabuhan Sunda Kelapa; (2) Pulau Ayer; (3) \\
& Pulau Bidadari; (4) Pulau Bira Besar; (5) Pulau \\
& Hantu Timur/Barat; (6) Pulau Kotok Tengah; (7) \\
& Pulau Kotok Timur; (8) Pulau Putri; (9) Pulau \\
& Sepa; (10) Pulau Matahari \\
& (1) Taman Impian Jaya Ancol; (2) Taman Mini \\
& Indonesia Indah; (3) Taman Margasatwa \\
Man-made Tourism & Ragunan; (4) Taman Monumen Nasional; (5) \\
& Taman Ismail Marzuki; (6) Taman Ria Senayan; \\
& (7) Perkemahan Cibubur; (8) Monumen Nasional; \\
& (9) Taman Kampung Wisata Rawajati; (10) \\
Taman Kampung Asri Banjarsari
\end{tabular}


This research is an explanatory research, which explains the relationship between variables and tests the hypothesis.

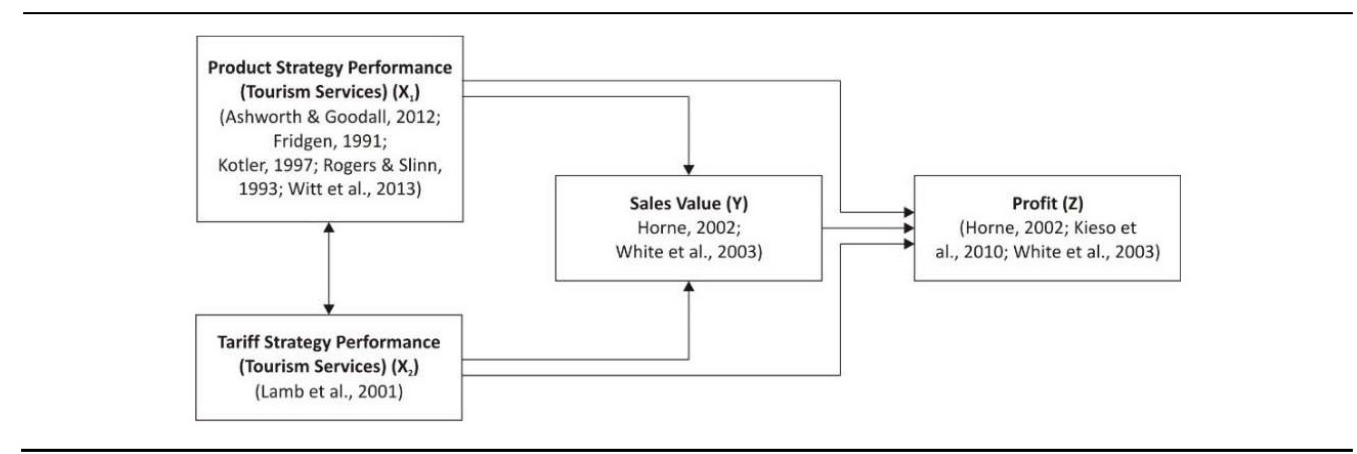

Figure 1. Research Framework

Table 2. Research Operational Variable

\begin{tabular}{|c|c|c|}
\hline Variable & Description & Indicator \\
\hline $\begin{array}{l}\text { Product Strategy } \\
\text { Performance }\left(X_{1}\right)\end{array}$ & $\begin{array}{l}\text { The results of consumer assessment } \\
\text { of all actions or benefits offered by } \\
\text { one party to another, which are } \\
\text { basically intangible and do not } \\
\text { result in ow nership. The product } \\
\text { can refer to a physical or non- } \\
\text { physical product (Ashworth \& } \\
\text { Goodall, 2012; Fridgen, 1991; Kotler, } \\
\text { 1997; Rogers \& Slinn, 1993; Witt et } \\
\text { al., 2013) }\end{array}$ & $\begin{array}{l}\text { Uniqueness, Diversity, } \\
\text { Design of Attractiveness, } \\
\text { Service, Punctuality of } \\
\text { Service, Diversity, } \\
\text { Accessibility, Security, } \\
\text { Parking Facilities, Toilets, } \\
\text { Places of Worship, Wartels, } \\
\text { ATMs, Clinics, Information } \\
\text { Centers, Waserbas, Souvenir } \\
\text { Shops, Public Transportation, } \\
\text { Availability of Safety } \\
\text { Support, Availability of } \\
\text { Supporting Information }\end{array}$ \\
\hline $\begin{array}{l}\text { Tariff Strategy } \\
\text { Performance }\left(X_{2}\right)\end{array}$ & $\begin{array}{l}\text { The results of the consumer's } \\
\text { assessment of the amount of tariff } \\
\text { (money) issued by consumers in } \\
\text { exchange for obtaining services } \\
\text { (Lamb et al., 2001) }\end{array}$ & $\begin{array}{l}\text { Tariff Suitability, Tariff } \\
\text { Attractiveness, Tariff } \\
\text { Satisfaction }\end{array}$ \\
\hline Sales (Y) & $\begin{array}{l}\text { Proceeds from sales (compensation } \\
\text { received by producers) which can } \\
\text { be measured directly from the } \\
\text { rupiah value generated (Horne, } \\
\text { 2002; White et al., 2003) }\end{array}$ & $\begin{array}{l}\text { The size of the sales value } \\
\text { obtained from the sale of } \\
\text { service products }\end{array}$ \\
\hline Profit (Z) & $\begin{array}{l}\text { The difference between sales and } \\
\text { total costs as an increase in assets } \\
\text { due to transactions and other events } \\
\text { that do not originate from the owner } \\
\text { (Horne, 2002; Kieso et al., 2010; } \\
\text { White et al., 2003) }\end{array}$ & $\begin{array}{l}\text { The size of the operating } \\
\text { profit on the sales results } \\
\text { obtained from the service } \\
\text { products sold }\end{array}$ \\
\hline
\end{tabular}


Product Strategy Performance and Tariff Strategy Performance is measured by the total score of all items on each variable of the consumer's assessment, while Sales Value is measured by the rupiah value (resulting from the sales process), and Profit is measured by net profit margin which involves operating profit and sales proceeds.

Research data collection techniques using questionnaires, interviews, documentation study. The questionnaire was distributed to each tourism business manager to determine the performance of the product strategy and tariff strategy. The questionnaire is structured on a Likert scale, with favorable statements (positive) with 5 answer options and a score order of 5-4-3-2-1. Structured interviews were conducted with the leaders of each tourism business, while secondary data were obtained through documentation studies sourced from company financial reports..

Questionnaire testing is done through item validity test and variable reliability test. Tests were carried out on the Product Strategy Performance $\left(X_{1}\right)$ and Tariff Strategy Performance $\left(\mathrm{X}_{2}\right)$ variables which were composed of Likert scale items. The validity test technique uses the correlation technique through the Product-Moment Correlation Coefficient (Pearson), while the reliability test technique used is the split-half correlation technique with the Spearman-Brown formula. To test the hypothesis, the analysis technique used is path analysis.

\section{RESULT AND DISCUSSION}

\section{Product Strategy Performance, Tariff Strategy, Sales Value, and Profits}

\section{Product Strategy Performance $\left(X_{1}\right)$}

The results of descriptive analysis show that the product strategy of all the tourism businesses studied has a high enough performance. Descriptive analysis is based on the median score of 30 respondents for each tourism service business. The proportion distribution of the 20 tourism businesses also has a high enough product strategy performance. This categorization is based on the total value of the median for all items (20 items) of the tourism service business. 
Table 3. Product Strategy Performance

\begin{tabular}{|c|c|c|c|c|c|c|c|c|}
\hline \multirow{2}{*}{ No } & \multirow{2}{*}{ Item (Indicator) } & \multicolumn{5}{|c|}{ Score Frequency } & \multirow{2}{*}{$\begin{array}{c}\text { Total } \\
\text { Median }\end{array}$} & \multirow{2}{*}{$\begin{array}{l}\text { Performance } \\
\text { Category }\end{array}$} \\
\hline & & 5 & 4 & 3 & 2 & 1 & & \\
\hline \multicolumn{9}{|c|}{ ATTRACTION } \\
\hline 1 & Uniqueness & 145 & 338 & 92 & 24 & 1 & $80(75,0 \%)$ & Unique \\
\hline 2 & Diversity of Attractions & 167 & 318 & 83 & 31 & 1 & $80(75,0 \%)$ & Varies \\
\hline 3 & Design of Attractiveness & 163 & 328 & 84 & 23 & 2 & $80(75,0 \%)$ & Interesting \\
\hline 4 & Service & 89 & 286 & 179 & 45 & 1 & $78,5(73,1 \%)$ & Adequate \\
\hline 5 & Punctuality of Service & 70 & 234 & 214 & 78 & 4 & $67,5(59,4 \%)$ & Quite Suit able \\
\hline \multicolumn{9}{|c|}{ REFRESHMENT } \\
\hline 6 & Diversity of Places to Eat/Drink & 181 & 320 & 69 & 27 & 3 & $80(75,0 \%)$ & Adequate \\
\hline 7 & Ease of Access to Places to Eat/Drink & 145 & 310 & 101 & 42 & 2 & $80(75,0 \%)$ & Easy \\
\hline \multicolumn{9}{|c|}{ SUPPORTING FACILITIES } \\
\hline 8 & Security & 106 & 243 & 171 & 73 & 7 & $75(68,8 \%)$ & Adequate \\
\hline 9 & Parking Facilities & 151 & 299 & 118 & 29 & 3 & $80(75,0 \%)$ & Adequate \\
\hline 10 & Toilets & 114 & 243 & 155 & 73 & 15 & $75,5(69,4 \%)$ & Adequate \\
\hline 11 & Places of Worship & 128 & 221 & 160 & 82 & 9 & $73,5(66,9 \%)$ & Adequate \\
\hline 12 & Wartels (Communication Facilities) & 27 & 152 & 258 & 151 & 12 & $61(51,3 \%)$ & Adequate \\
\hline 13 & ATMs & 38 & 123 & 253 & 164 & 22 & $59,5(49,4 \%)$ & Inadequate \\
\hline 14 & Clinics & 37 & 125 & 215 & 192 & 31 & $56(45,0 \%)$ & Inadequate \\
\hline 15 & Information Centers & 79 & 278 & 169 & 70 & 4 & $76,5(70,6 \%)$ & Adequate \\
\hline 16 & Waserbas & 40 & 203 & 257 & 97 & 3 & $62,5(53,1 \%)$ & Adequate \\
\hline 17 & Souvenir Shops & 108 & 343 & 116 & 30 & 3 & $80(75,0 \%)$ & Adequate \\
\hline 18 & Public Transportation & 64 & 242 & 168 & 110 & 16 & $70,5(63,1 \%)$ & Adequate \\
\hline \multicolumn{9}{|c|}{ OTHER INFRASTRUCTURE } \\
\hline 19 & Availability of Safety Support & 116 & 218 & 180 & 74 & 12 & $74(67,5 \%)$ & Adequate \\
\hline 20 & $\begin{array}{l}\text { Availability of Supporting } \\
\text { Information }\end{array}$ & 119 & 339 & 117 & 22 & 3 & $79,5(74,4 \%)$ & Adequate \\
\hline \multicolumn{7}{|c|}{ Product Strategy Performance } & $\begin{array}{r}1469,5 \\
(66,8 \%) \\
\end{array}$ & High Enough \\
\hline
\end{tabular}

Less ( $0 \% \leq \%$ Total Median < 25\%); Low ( $25 \% \leq \%$ Total Median < $50 \%)$

Adequate $(50 \% \leq \%$ Total Median $<75 \%)$; High $(75 \% \leq \%$ Total Median $\leq 100 \%)$

ATTRACTION. For unique attractions, Pulau Sepa has the most unique attractions, because there are attractions related to the conservation of marine life and the natural tropical island atmosphere. In terms of diversity of attractions, Pulau Matahari has a variety of marine attractions, nature and beautiful sea views. For the design of attractiveness, Taman Margasatwa Ragunan has advantages related to the design of an open zoo concept where visitors seem to be in the middle of an animal habitat. Taman Impian Jaya Ancol 
excels in the availability of services in attractions, because most of the attractions presented require technology support. Taman Impian Jaya Ancol also excels in terms of punctuality of service, because the attractions provided must take place according to schedule.

REFRESHMENT. Pulau Ayer has a variety of places to eat and drink, where there are many variations of eating and drinking places provided for tourists. Pulau Kotok Tengah and Pulau Putri have easy access to places to eat and drink. The tourism business managers on these two islands are able to arrange the location of places to eat and drink so that they are easily accessible to tourists.

SUPPORTING FACILITIES. The availability of adequate security facilities can be found at Taman Impian Jaya Ancol, because there are many risky tourist attractions that need careful attention. The area of available parking space is owned by Pulau Putri, where each tourist area on Pulau Putri is equipped with a large parking area. Pulau Putri also has adequate toilet availability from other tourist attractions. For places of worship, Pulau Bidadari has the highest availability of places of worship. Communication facilities for visitors are owned by Taman Impian Jaya Ancol, which is supported by various modern technological devices. The availability of ATM facilities is owned by Pulau Ayer, which makes it easier for tourists to make banking transactions (withdraw cash). In terms of clinic availability, Taman Margasatwa Ragunan has the highest clinic availability. Meanwhile, Pulau Putri has the highest availability of information centers. In terms of availability of Waserba, Taman Margasatwa Ragunan has the highest availability of Waserba to meet the needs of visitors, most of whom are families who bring children. Taman Mini Indonesia Indah has the highest availability of souvenir shops; as a tourist attraction that presents the diversity of Indonesian culture, these shops provide many unique souvenirs from every region in Indonesia. Meanwhile, the highest availability of public transportation services is owned by the National Monument Park, which benefits from being in the city center.

OTHER INFRASTRUCTURE. The aspect of the highest availability of safety support is owned by Taman Mini Indonesia Indah. This also shows the high attention of Taman Mini Indonesia Indah managers to the safety of tourists. Taman Mini Indonesia Indah is also considered to have the highest availability of supporting information. 


\section{Tariff Strategy Performance $\left(X_{2}\right)$}

The results of the descriptive analysis show that in general the tariff strategy of all the tourism businesses studied has a fairly high performance. The total value of the median for all items (5 items) and all tourism service businesses (20 tourism service businesses) was $352.5(63.1 \%)$.

Table 4. Tariff Strategy Performance

\begin{tabular}{|c|c|c|c|c|c|c|c|c|}
\hline \multirow{2}{*}{ No } & \multirow{2}{*}{ Item (Indicator) } & \multicolumn{5}{|c|}{ Score Frequency } & \multirow{2}{*}{$\begin{array}{l}\text { Total } \\
\text { Median }\end{array}$} & \multirow{2}{*}{$\begin{array}{l}\text { Performance } \\
\text { Category }\end{array}$} \\
\hline & & 5 & 4 & 3 & 2 & 1 & & \\
\hline \multicolumn{9}{|c|}{ KESESUAIAN TARIF } \\
\hline 1 & Price Compatibility with Facilities & 94 & 297 & 128 & 76 & 5 & $77,5(71,9 \%)$ & Quite Suitable \\
\hline \multicolumn{9}{|c|}{ SUPPORTING FACILITIES } \\
\hline 2 & Attractiveness of The Service Price & 59 & 246 & 192 & 95 & 8 & $68,5(60,6 \%)$ & Quite Interesting \\
\hline 3 & Entrance Price & 75 & 160 & 182 & 155 & 28 & $64,5(55,6 \%)$ & Cheap Enough \\
\hline 4 & $\begin{array}{l}\text { Tariff Compatibility with Service } \\
\text { Facilities }\end{array}$ & 71 & 244 & 179 & 96 & 10 & $71,5(64,4 \%)$ & Quite Suitable \\
\hline \multicolumn{9}{|c|}{ OTHER INFRASTRUCTURE } \\
\hline 5 & Service Satisfaction & 77 & 245 & 195 & 69 & 14 & $70,5(63,1 \%)$ & Quite Suitable \\
\hline \multicolumn{7}{|c|}{ Tariff Strategy Performance } & $\begin{array}{r}352,5 \\
(63,1 \%)\end{array}$ & High Enough \\
\hline
\end{tabular}

Less ( $0 \% \leq \%$ Total Median < 25\%); Low (25\% $\leq \%$ Total Median $<50 \%$ )

Adequate $(50 \% \leq \%$ Total Median $<75 \%)$; High $(75 \% \leq \%$ Total Median $\leq 100 \%)$

Based on the three dimensions in Table 4. above, all of them are owned by Taman Impian Jaya Ancol: price compatibility with the facilities, attractiveness of the highest service price, the lowest entrance price, tariff compatibility with the highest service facilities, and service satisfaction with the highest sacrifice. 


\section{Sales Value $(Y)$}

The sales value for each tourism business certainly has a high difference because it is influenced by the level of tourist visits. In addition, there is also the availability of human resources, which is the main factor in developing creative values to increase tourist visits.

Table 5. The Average Sales Value of the Tourism Business

\begin{tabular}{clc}
\hline No & \multicolumn{1}{c}{ Tourist Attraction } & Sales (Rp) \\
\hline 1 & Taman Impian Jaya Ancol & 563.157 .213 .200 \\
2 & Taman Mini Indonesia Indah & 61.180 .776 .313 \\
3 & Taman Margasatwa Ragunan & 10.530 .795 .587 \\
4 & Taman Monumen Nasional & 2.753 .485 .516 \\
5 & Taman Ismail Marzuki & 274.911 .121 \\
6 & Taman Ria Senayan & 716.422 .310 \\
7 & Taman Perkemahan Cibubur & 267.961 .376 \\
8 & Taman Monumen Pancasila Sakti & 59.871 .420 \\
9 & Taman Kampung Wisata Rawajati & 13.151 .138 \\
10 & Taman Kampung Asri Banjarsari & 14.184 .190 \\
11 & Pelabuhan Sunda Kelapa & 19.948 .526 \\
12 & Pulau Ayer & 2.098 .198 .230 \\
13 & Pulau Bidadari & 2.499 .445 .006 \\
14 & Pulau Bira Besar & 947.250 .190 \\
15 & Pulau Hantu Timur/ Barat & 1.241 .468 .710 \\
16 & Pulau Kotok Tengah & 856.503 .428 \\
17 & Pulau Kotok Timur & 205.584 .450 \\
18 & Pulau Matahari & 2.068 .657 .350 \\
19 & Pulau Putri & 3.616 .237 .100 \\
20 & Pulau Sepa & 1.867 .873 .235 \\
\hline
\end{tabular}

Sources: Financial Report (2001-2005)

4. Profit $(\mathrm{Z})$

In addition to showing differences in income, the difference in net profit margin (NPM) also shows differences in efficiency factors in each tourism business in order to generate profits. 
Table 6. Profit (Net Profit Margin) from The Tourism Business

\begin{tabular}{clcc}
\hline No & \multicolumn{1}{c}{ Tourist Attraction } & Net Profit (Rp) & NPM \\
\hline 1 & Taman Impian Jaya Ancol & 9.934 .549 .468 & $2,63 \%$ \\
2 & Taman Mini Indonesia Indah & 2.960 .101 .464 & $4,54 \%$ \\
3 & Taman Margasatwa Ragunan & 1.799 .883 .442 & $17,17 \%$ \\
4 & Taman Monumen Nasional & 979.245 .661 & $36,78 \%$ \\
5 & Taman Ismail Marzuki & 28.829 .674 & $10,39 \%$ \\
6 & Taman Ria Senayan & 20.107 .071 & $2,77 \%$ \\
7 & Taman Perkemahan Cibubur & 13.681 .401 & $5,57 \%$ \\
8 & Taman Monumen Pancasila Sakti & 3.814 .990 & $6,79 \%$ \\
9 & Taman Kampung Wisata Rawajati & 1.033 .364 & $7,70 \%$ \\
10 & Taman Kampung Asri Banjarsari & 1.708 .115 & $11,68 \%$ \\
11 & Pelabuhan Sunda Kelapa & 1.171 .786 & $5,63 \%$ \\
12 & Pulau Ayer & 408.300 .676 & $18,74 \%$ \\
13 & Pulau Bidadari & 287.016 .756 & $10,66 \%$ \\
14 & Pulau Bira Besar & 183.771 .934 & $17,82 \%$ \\
15 & Pulau Hantu Timur/ Barat & 144.827 .426 & $10,90 \%$ \\
16 & Pulau Kotok Tengah & 156.953 .998 & $18,09 \%$ \\
17 & Pulau Kotok Timur & 24.249 .405 & $11,44 \%$ \\
18 & Pulau Matahari & 224.881 .115 & $9,96 \%$ \\
19 & Pulau Putri & 187.191 .800 & $4,82 \%$ \\
20 & Pulau Sepa & 174.277 .766 & $9,26 \%$ \\
\hline
\end{tabular}

Sources: Financial Report (2001-2005)

\section{Relationship between Product Strategy Performance and Tariff Strategy Performance}

The correlation between Product Strategy Performance $\left(X_{1}\right)$ and Tariff Strategy $\left(X_{2}\right)$ is shown by the correlation coefficient $r_{x 2 \times 1}=0,4489$. Referring to the correlation coefficient value, the closeness of the relationship between the two strategies is quite high (Guilford, 1967). This means that the research hypothesis $\left(\mathrm{H}_{1}\right)$ is accepted, because the correlation coefficient $r>0,20$. So, the Product Strategy Performance is related to the Tariff Strategy Performance, and the direction of the relationship between the two independent variables is positive which indicates that a tourism business that has a higher Product Strategy Performance has a higher Tariff Strategy Performance. 
Based on this assessment, the company should be able to improve internal business processes related to developing the right product and determining the appropriate tariff (Kaplan et al., 2001). If the internal business process is carried out properly, customers will feel satisfied and loyal to companies that have unique products and tourist attractions.

\section{The Impact of Product Strategy Performance and Tariff Strategy on Sales Value}

The amount of variation in Sales Value caused by two independent variables is $37.35 \%$. The remaining $62.65 \%$ or $1-\mathrm{R}^{2}$, are explained by various other unexplored factors. 5 variations The direct and indirect effects that break down the total effect can be seen in Table 7. below.

\section{Table 7. Contribution of the Effect of Product Strategy Performance and Tariff Strategy on Sales Value}

\begin{tabular}{|c|c|c|c|c|c|c|c|}
\hline & \multirow{2}{*}{\multicolumn{2}{|c|}{$\begin{array}{l}\text { Pengaruh } \\
\text { Langsung }\end{array}$}} & \multicolumn{4}{|c|}{ Pengaruh tidak langsung, melalui } & \multirow{2}{*}{$\begin{array}{c}\text { Pengaruh } \\
\text { Total }\end{array}$} \\
\hline & & & $\mathrm{X}_{1}$ & $\mathrm{X}_{2}$ & SubTotal & & \\
\hline$\overline{X_{1}}$ & $1,68 \%$ & + & - & $3,15 \%$ & $3,15 \%$ & + & \begin{tabular}{l|l}
$4,83 \%$ \\
\end{tabular} \\
\hline $\mathrm{X}_{2}$ & $29,37 \%$ & + & $3,15 \%$ & - & $3,15 \%$ & + & $32,52 \%$ \\
\hline \multicolumn{7}{|c|}{ Pengaruh total variabel $X_{1}$ dan $X_{2}$ terhadap $Y$} & $37,35 \%$ \\
\hline & & & \multicolumn{4}{|c|}{ Pengaruh variabel lain $\varepsilon_{1}$ terhadap $Y$} & $62,65 \%$ \\
\hline & & & \multicolumn{4}{|c|}{ Total } & $100,00 \%$ \\
\hline
\end{tabular}

Meanwhile, referring to the value of multiple correlation coefficients (the root of $R^{2}$ ): $\mathrm{R}=0.6112$, indicating the effect of two independent variables simultaneously is moderate or strong enough. (Guilford, 1967). Thus, the research hypothesis $\left(\mathrm{H}_{2}\right)$ regarding the effect of Product Strategy Performance $\left(X_{1}\right)$ and Tariff Strategy Performance $\left(X_{2}\right)$ on Sales Value $(\mathrm{Y})$ is simultaneously accepted. However, the hypothesis regarding the effect of Product Strategy Performance $\left(X_{1}\right)$ on Sales Value $(Y)$ is weak. So, the effect of Product Strategy Performance $\left(\mathrm{X}_{1}\right)$ on Sales Value $(\mathrm{Y})$ is partially rejected.

Table 8. Partial Effect Contribution Test Results

\begin{tabular}{lcccc}
\hline \multicolumn{1}{c}{ Partial Influence } & pyxi & $\mathbf{p}^{2} \mathbf{Y X i}$ & Category & Decision \\
\hline $\begin{array}{l}\text { Product Strategy } \\
\text { Performance }\left(\mathrm{X}_{1}\right)\end{array}$ & 0,1295 & $1,68 \%$ & Very Weak & Hypothesis \\
$\begin{array}{l}\text { Tariff Strategy Performance } \\
\left(\mathrm{X}_{2}\right)\end{array}$ & 0,5420 & $29,37 \%$ & $\begin{array}{c}\text { Strong } \\
\text { Enough }\end{array}$ & $\begin{array}{c}\text { Hypothesis } \\
\text { Accepted }\end{array}$ \\
\hline
\end{tabular}

Note: $p_{y x i}=$ path coefficient, $p^{2}{ } x_{i}=$ direct influence 
The table above shows that only the Tariff Strategy Performance $\left(X_{2}\right)$ partially affects the Sales Value (Y). This shows that the effect of the Tariff Strategy is partially more dominant than the influence of the Product Strategy Performance.

\section{The Impact of Product Strategy Performance, Tariff Strategy and Sales Value on Profits}

The amount of variation in profit generated simultaneously is $20.67 \%$, and the remaining $79.33 \%$ or $1-\mathrm{R}^{2}$ is explained by other factors not examined in this study. The direct and indirect effects that describe the total effect of the three variables $\left(X_{1}, X_{2}\right.$, and $\left.Y\right)$ can be seen in Table 9. as follows.

Table 9. Contribution of the Influence of Product Strategy Performance, Tariff Strategy and Sales Value to Profits

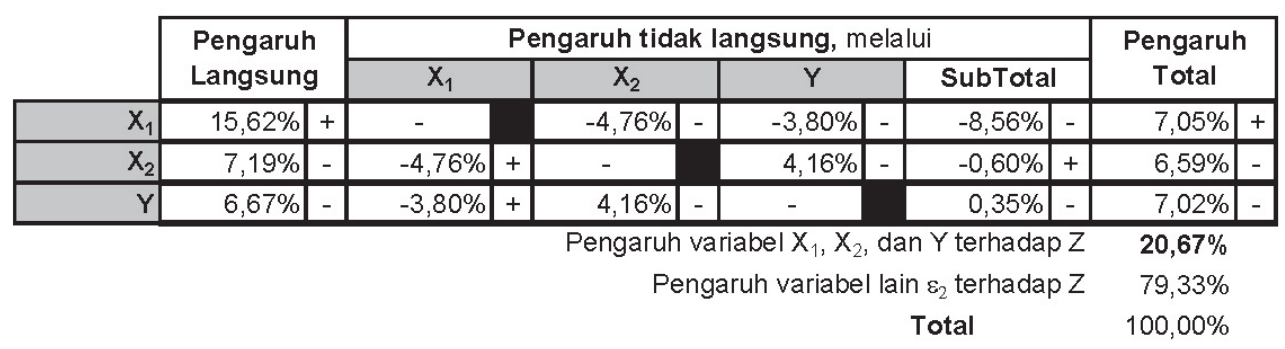

The value of multiple correlation coefficients (the root of $R^{2}$ ) is $R=0.4547$. This value indicates that the effect of three causal variables simultaneously is moderate or strong enough (Guilford, 1967). This means that the research hypothesis $\left(\mathrm{H}_{3}\right)$ regarding the influence of Product Strategy Performance $\left(X_{1}\right)$, Tariff Strategy Performance $\left(X_{2}\right)$, and Sales Value $(\mathrm{Y})$ on Profit $(\mathrm{Z})$ is simultaneously accepted. Meanwhile, the partial influence of the three causal variables on Profit $(Z)$ can be seen in Table 10. below.

Table 10. Partial Effect Contribution Test Results

\begin{tabular}{lcccc}
\hline \multicolumn{1}{c}{ Partial Influence } & $\mathbf{p}_{\mathrm{Zi}}$ & $\mathbf{p}^{2} \mathrm{Zi}$ & Category & Decision \\
\hline $\begin{array}{l}\text { Product Strategy Performance } \\
\left(\mathrm{X}_{1}\right)\end{array}$ & 0,3952 & $15,62 \%$ & Weak & $\begin{array}{c}\text { Hypothesis } \\
\text { Accepted }\end{array}$ \\
$\begin{array}{l}\text { Tariff Strategy Performance } \\
\left(\mathrm{X}_{2}\right)\end{array}$ & $-0,2682$ & $7,19 \%$ & Weak & $\begin{array}{c}\text { Hypothesis } \\
\text { Accepted }\end{array}$ \\
Sales Value $(\mathrm{Y})$ & $-0,2583$ & $6,67 \%$ & Weak & $\begin{array}{c}\text { Hypothesis } \\
\text { Accepted }\end{array}$ \\
\hline
\end{tabular}




\section{Discussion}

DKI Jakarta Province has great potential in tourism development. Apart from being the center of the national economic activity, the infrastructure and accessibility networks for developing tourism potential in DKI Jakarta are also adequate. The availability of infrastructure support and accessibility is one of the requirements to increase the growth rate of the tourism sector (Moerwanto \& Junoasmono, 2017; Priatmoko, 2017). Without support of adequate infrastructure and accessibility networks, tourists will be reluctant to visit.

The challenge is how to formulate a comprehensive tourism development strategy so that it will attract more tourist visits (Hermansyah, 2019). Without a comprehensive development strategy, efforts to increase tourist visits will be difficult to achieve. These development strategies include infrastructure development, promotion (marketing), strengthening human resources, involving the private sector (Mongkol, 2016). In another study, the development strategy was carried out through tourism object development, tourism promotion/marketing and tourism business development (Nurhadi et al., 2014).

In the research of Nurhadi et al. (2014), a tourism development strategy through promotion is carried out by holding events and festivals, while in Mongkol's research (2016) the strategy was implemented by forming regional tourism travel organizations, managing promotional media, developing tourist attraction activities \& regional tourism marketing services. It is hoped that the implementation of this strategy will contribute to increasing PAD (Mongkol, 2016; Nurhadi et al., 2014).

Meanwhile, to develop the potential of tourism sector in DKI Jakarta Province, this study emphasizes the importance of developing a product and tariff strategy, which in turn can affect sales and profits. As a solution model for increasing sales value and profit, the results show that efforts to increase sales value can be done by improving product and tariff strategies. Improved product strategy performance has a stronger impact on increasing operating income, while an increase in tariff strategy has a strong impact on increasing sales value.

As dominant determinant of sales value and referring to the results of descriptive analysis of the tariff strategy performance indicators, the efforts that can be made by the DKI Jakarta Provincial Government to improve the performance of the tariff strategy are: (1) suitability between price and facilities; (2) attractiveness of service prices; (3) relevant entry prices; (4) suitability between tariffs and service facilities; and (5) service satisfaction which is equivalent to consumer sacrifice.

Meanwhile, as the dominant determinant of operating profit, and by referring to the results of descriptive analysis of the product strategy performance indicators, the efforts that can be made by the DKI Jakarta Provincial Government are: (1) increasing service availability, punctuality of service as promised, improving security facilities, availability 
of toilets, places of worship, communication facilities, information centers, washbasins, public transportation services, supporting safety and information, and the availability of clinics and ATMs.

However, this development strategy may be difficult to apply to the tourist objects that are not managed by the local government, unless there is a role from the DKI Jakarta Provincial government in determining entrance fee or internal policies between tourism service companies in regulating tariffs for products sold to public. It is also an attempt to protect tourists' rights (Kristina et al., 2019; Oktaviarni, 2018).

In context of implementing tariff strategy for tourism businesses managed by DKI Jakarta Provincial government, such as Taman Impian Jaya Ancol, Taman Margasatwa Ragunan (Kebun Binatang Ragunan), Taman Mini Indonesia Indah (TMII), and Taman Monumen Nasional (Monas), what is needed is a tariff regulation regulation. However, regulation must also be applied with care so that it does not have an impact on decreasing tourist visits (Jayanti, 2013).

The application of product and tariff strategies is also expected to contribute to an increase in PAD, which comes from hotel taxes, restaurant taxes, and levies for recreation areas (Astuti, 2019; Jaenuddin, 2019; Puspitasari et al., 2018). Another contribution from this sector is the expansion of employment opportunities for the community (Hakim, 2017; Isniati \& Yusrini, 2019). This can be seen, for example, from the operation of hotels and inns, restaurants, travel businesses, souvenir shops, entertainment (event) (Darsini \& Darsana, 2014; Rismiyanto \& Danangdjojo, 2015; Sanaubar et al., 2017; Santoso, 2014; Setiyanti \& Sadono, 2011). This means that domestic and foreign tourist visits to various tourist objects in the DKI Jakarta Province will indirectly open up job opportunities for the local people, and in turn are expected to help reduce unemployment.

\section{CONCLUSION}

This study shows that the model of the influence of the factors studied on Sales Value and Profit in the tourism business has a high degree of suitability. The findings in this study reconceptualize the concept of product strategy performance, tariff strategy performance, sales, and profit as a tourism business financial performance, especially in a synergy model between product and tariff strategies to increase sales and tourism business performance. The results of the model analysis also show that the increase in sales value in the tourism business in DKI Jakarta Province should be able to focus on optimizing the tariff strategy, while increasing profits can be focused on improving product strategy. 


\section{SUGGESTION}

To optimize strategic performance of tourism service products in DKI Jakarta Province, suggestions that can be given are improving the availability of services, the timeliness of services in the tourist attractions that are served, and also completing various supporting facilities such as supporting facilities for safety and information. Meanwhile, to increase the contribution of the tourism sector to Local Own-Source Revenue (PAD), DKI Jakarta Provincial Government can issue policies to support fair business competition, organize a healthy business environment, and encourage tourism product innovation.

\section{REFERENCE}

Alisher, E. (2017). Innovative Marketing Strategy for Tourism Development. World Scientific News, 88(2), 58-68.

Annisarizki, \& Sucahya, M. (2018). Manajemen Wisata Religius Kesultanan Banten (Bauran Komunikasi Pemasaran dalam Meningkatkan Jumlah Wisatawan). Nyimak: Journal of Communication, 2(2), 187-205.

Antara, M., \& Sumarniasih, M. S. (2017). Role of Tourism in Economy of Bali and Indonesia. Journal of Tourism and Hospitality Management, 5(2), 34-44.

AntaraNews. (2019, March 14). Capaian PAD DKI Tahun 2019 dari Pariwisata Menunjukan Tren Positif. https://www.antaranews.com/berita/809815/capaian-pad-dki-tahun2019-dari-pariwisata-menunjukan-tren-positif

Anwar, M. F., Hamid, D., \& Topowijono, T. (2017). Analisis Dampak Pengembangan Wisata Religi Makam Sunan Maulana Malik Ibrahim dalam Kehidupan Sosial dan Ekonomi Masyarakat Sekitar (Studi pada Kelurahan Gapurosukolilo Kabupaten Gresik). Jurnal Administrasi Bisnis (JAB), 44(1), 186-193.

Ashworth, G. J., \& Goodall, B. (2012). Marketing Tourism Places. Routledge.

Astuti, A. (2019). Pengaruh Penerimaan Pajak Restoran terhadap Pendapatan Asli Daerah Kota Bandung. JASa (Jurnal Akuntansi, Audit Dan Sistem Informasi Akuntansi), 3(2), 287-297.

Basera, V. (2018). Tourism Marketing Strategies and Domestic Tourism Demand in Kariba Resort (Zimbabwe). Journal of Tourism E Hospitality, 7(2), 1-7. https:/ / doi.org/10.4172/ 2167-0269.1000344

Darsini, N. N. A., \& Darsana, I. B. (2014). Pengaruh Kunjungan Wisatawan, Luas Artshop dan Lokasi Artshop Terhadap Penyerapan Tenaga Kerja Bisnis Artshop di Kawasan Nusa Dua | E-Jurnal Ekonomi Pembangunan Universitas Udayana. E-Jurnal Ekonomi Pembangunan, 3(5), 173-226.

Font, X., \& McCabe, S. (2017). Sustainability and marketing in tourism: Its contexts, paradoxes, approaches, challenges and potential. Journal of Sustainable Tourism, 25(7), 869-883. https:// doi.org/10.1080/09669582.2017.1301721 
Fridgen, J. (1991). Dimensions of Tourism. Educational Institute of the American Hotel Motel Assoc. https://www.abebooks.com/9780866121040/Dimensions-TourismJoseph-Fridgen-0866121048/plp

Guilford, J. P. (1967). Fundamental Statistics in Psychology and Education. McGraw-Hill Kogakusha Company. Ltd.

Hakim, A. R. (2017). Profil Potensi Sektor Pariwisata di Provinsi DKI Jakarta. https:// $\mathrm{w}$ w w. $\mathrm{r}$ e $\mathrm{s}$ e a $\mathrm{r} \mathrm{c} \mathrm{h}$ a $\mathrm{t}$. $\mathrm{n}$ e $\mathrm{t} / \mathrm{p} \mathrm{u} b \mathrm{l}$ i a $\mathrm{t}$ i o n / 329884947_Profil_Potensi_Sektor_Pariwisata_di_Provinsi_DKI_Jakarta

Hermansyah. (2019, January 11). Pariwisata Jakarta Membutuhkan Pembenahan. https:// www.alinea.id/bisnis/pariwisata-jakarta-membutuhkan-pembenahan-b1WZ09gGa

Hieu, V. M., \& Yen, H. T. B. (2019). Analysing economic contribution of tourism: Insights from selected Southeast Asian countries. Management, 23(2), 223-237. https:/ / doi.org/ 10.2478/manment-2019-0028

Holik, A. (2016). Relationship of Economic Growth with Tourism Sector. Journal of Economics and Policy, 9(1), 16-33.

Horne, J. C. V. (2002). Financial Management and Policy. Prentice Hall.

Isniati, B., \& Yusrini, B. A. (2019). Peran Ekonomi Kreatif Sektor Kerajinan untuk Mengurangi Tingkat Pengangguran di Desa Taman Sari Kecamatan Gunungsari Kabupaten Lombok Barat. SOCIETY, 10(2), 154-162.

Jaenuddin, Muh. T. (2019). Upaya Peningkatan Pendapatan Asli Daerah melalui Pengembangan Pariwisata di Kabupaten Mamuju. Government: Jurnal Ilmu Pemerintahan, 12(2), 67-71.

Jayanti, S. D. (2013). Tinjauan Kenaikan Harga Tiket dengan Volume Kunjungan di Pusat Konservasi Tumbuhan Kebun Raya Bogor (PKT KRB) - Lipi. Thesis: Sekolah Tinggi Ilmu Ekonomi Kesatuan.

Kaplan, R. S., Davenport, T. H., Robert, N. P. D. K. S., Kaplan, R. S., \& Norton, D. P. (2001). The Strategy-focused Organization: How Balanced Scorecard Companies Thrive in the New Business Environment. Harvard Business Press.

Kieso, D. E., Weygandt, J. J., \& Warfield, T. D. (2010). Intermediate Accounting: IFRS Edition. John Wiley \& Sons.

Kotler, P. (1997). Marketing Management: Analysis, Planning, Implementation, and Control. Prentice Hall.

Krishnamurthi, L., \& Raj, S. P. (1991). An Empirical Analysis of the Relationship between Brand Loyalty and Consumer Price Elasticity. Marketing Science, 10(2), 172-183. JSTOR.

Kristina, N. M. R., Putra, I. B. K. S., \& Darma, I. G. K. I. P. (2019). Peran Kenaikan Harga Tiket Pesawat dengan Kunjungan Wisatawan ke Bali pada Era Industri 4.0. Jurnal Pariwisata Budaya, 4(2), 76-86. 
Kurniawati, E., Hamid, D., \& Hakim, L. (2018). Peran Masyarakat dalam Perencanaan dan Pengembangan Desa Wisata Tulungrejo Kecamatan Bumiaji Kota Batu. Jurnal Administrasi Bisnis (JAB), 54(1), 8-14.

Kusuma, C. S. D. (2019). Mice-Masa Depan Bisnis Pariwisata Indonesia. Jurnal Efisiensi - Kajian Ilmu Administrasi, XVI(2), 52-62.

Lamb, C. W., Hair, J. F., \& McDaniel, C. D. (2001). Essentials of Marketing. South-Western College Pub.

Manzoor, F., Wei, L., Asif, M., Haq, M. Z. ul, \& Rehman, H. ur. (2019). The Contribution of Sustainable Tourism to Economic Growth and Employment in Pakistan. International Journal of Environmental Research and Public Health, 16(19).

Moerwanto, A. S., \& Junoasmono, T. (2017). Strategi Pembangunan Infrastruktur Wisata Terintegrasi. Jurnal HPJI, 3(2), 67-78.

Mongkol, C. (2016). Strategi Dinas Pariwisata dalam Mengembangkan Potensi Wisata Budaya di Kabupaten Minahasa. Jurnal Politico, 5(1), 1-12.

Mulhern, F. J., \& Leone, R. P. (1991). Implicit Price Bundling of Retail Products: A Multiproduct Approach to Maximizing Store Profitability: Journal of Marketing, 55(4), 63-76. https:// doi.org/10.1177/002224299105500405

Nugraha, R. N., Yuliantini, T., \& Karyatun, S. (2019). Tren Pariwisata DKI Jakarta. Jurnal Riset Manajemen Dan Bisnis (JRMB), 4(2), 317-328.

Nurhadi, F. D. C., Mardiyono, \& Rengu, S. P. (2014). Strategi Pengembangan Pariwisata oleh Pemerintah Daerah terhadap Pendapatan Asli Daerah (Studi pada Dinas Pemuda, Olahraga, Kebudayaan dan Pariwisata Kabupaten Mojokerto). Jurnal Administrasi Publik (JAP), 2(2), 325-331.

Nyström, H., Tamsons, H., \& Thams, R. (1975). An Experiment in Price Generalization and Discrimination. Journal of Marketing Research, 12(2), 177-181. https://doi.org/ $10.1177 / 002224377501200207$

Ohlan, R. (2017). The relationship between tourism, financial development and economic growth in India. Future Business Journal, 3(1), 9-22. https://doi.org/10.1016/ j.fbj.2017.01.003

Oktaviarni, F. (2018). Perlindungan Hukum terhadap Wisatawan menurut UndangUndang Nomor 10 Tahun 2009 tentang Kepariwisataan. Wajah Hukum, 2(2), 138145.

Pop, I., Kanovici, A., Ghic, G., \& Andrei, M. (2016). The Economic Effects of the Mega Sport Events on Tourism in the BRICS Countries Case. Amfiteatru Economic Journal, 18(Special Issue No. 10), 960-975.

Priatmoko, S. (2017). Pengaruh Atraksi, Mediasosial, Dan Infrastruktur Terhadap Keputusan Berkunjung Wisatawan Ke Desa Wisata Pentingsari Yogyakarta. Khasanah Ilmu - Jurnal Pariwisata Dan Budaya, 8(1), Article 1. https://doi.org/10.31294/ khi.v8i1.1940 
Purwomarwanto, Y. L., \& Ramachandran, J. (2015). PERFORMANCE OF TOURISM SECTOR WITH REGARD TO THE GLOBAL CRISIS - A COMPARATIVE STUDY BETWEEN INDONESIA, MALAYSIA AND SINGAPORE. The Journal of Developing Areas, 49(4), 325-339.

Puspitasari, I., Saleh, Moh., \& Yunitasari, D. (2018). Analisis Kontribusi Sektor Priwisata Terhadap Pendapatan Asli Daerah Kota Batu Periode Tahun 2011-2015. E-Journal Ekonomi Bisnis Dan Akuntansi, 5(1), 11-15.

Rahayu, I. (2018). Dampak Penyelenggaraan Event Pariwisata Dragon Boat Race di Kota Tanjungpinang. JUMPA, 5(1), 211-226.

Rahma, A. A. (2020). Potensi Sumber Daya Alam dalam Mengembangkan Sektor Pariwisata di Indonesia. Jurnal Nasional Pariwisata, 12(1), 1-8.

Ratnawati, Y. (2016). Analisis Kontribusi Sektor Pariwisata terhadap Pendapatan Asli Daerah Kabupaten Kutai Timur. Ekonomia, 5(3), 473-479.

Reibstein, D. J., \& Gatignon, H. (1984). Optimal Product Line Pricing: The Influence of Elasticities and Cross-Elasticities. Journal of Marketing Research, 21(3), 259-267. https:/ / doi.org/10.1177/002224378402100303

Reisha, T. (2019, June 27). Beragam Program Pariwisata Dongkrak Pendapatan Asli Daerah. detikTravel. https:/ / travel.detik.com/travel-news/d-4602950/ beragam-programpariwisata-dongkrak-pendapatan-asli-daerah

Rismiyanto, E., \& Danangdjojo, T. (2015). Dampak Wisata Kuliner Oleh-oleh Khas Yogyakarta terhadap Perkonomian Masyarakat. Jurnal MAKSIPRENEUR, 5(1), 46 64.

Rogers, A., \& Slinn, J. (1993). Tourism: Management of Facilities. Pitman.

Sanaubar, G., Hidayat, W., \& Kusuma, H. (2017). Pengaruh Potensi Pariwisata terhadap Penyerapan Tenaga Kerja Sektor Perhotelan di 9 Kabupaten/Kota Provinsi Jawa Timur Tahun 2012-2015. Jurnal Ilmu Ekonomi, 1(3), 324 - 339.

Santoso. (2014). Analisis Pertumbuhan Jumlah Kamar Hotel, Jumlah Wisatawan dan Mahasiswa Perguruan Tinggi Pariwisata Program Studi Perhotelan. Jurnal Media Wisata, 12(1), 43-69.

Selnes, F. (1993). An Examination of the Effect of Product Performance on Brand Reputation, Satisfaction and Loyalty. European Journal of Marketing, 27(9), 19-35. https:/ / doi.org/10.1108/03090569310043179

Setiyanti, D., \& Sadono, D. (2011). Dampak Pariwisata terhadap Peluang Usaha dan Kerja Luar Pertanian Di Daerah Pesisir. Sodality: Jurnal Sosiologi Pedesaan, 5(3), 259272. https:/ / doi.org/10.22500/ sodality.v5i3.9692

Simamora, R. K., \& Sinaga, R. S. (2016). Peran Pemerintah Daerah dalam Pengembangan Pariwisata Alam dan Budaya di Kabupaten Tapanuli Utara. Jurnal Ilmu Pemerintahan Dan Sosial Politik UMA, 4(1), 79-96. 
Simangunsong, F., \& Tahir, M. (2018). Strategy of Local Government in Tourism Development of Marina Beach in Bantaeng Regency South Sulawesi Province. Open Journal of Social Sciences, 06, 43-66. https://doi.org/10.4236/jss.2018.61004

Singgalen, Y. A., Sasongko, G., \& Wiloso, P. G. (2019). Community Participation in Regional Tourism Development: A Case Study in North Halmahera RegencyIndonesia. Insights into Regional Development, 1(4), 318-333.

Soeswoyo, D. M. (2019). Kontribusi Sektor Pariwisata dan Realisasi Rencana Induk Pembangunan Kepariwisataan Kota. Jurnal Sosial Humaniora, 10(2), 108-119. https:/ / doi.org/10.30997/jsh.v10i2.2024

Suhel, S., \& Bashir, A. (2018). The Role of Tourism toward Economic Growth in The Local Economy. Economic Journal of Emerging Markets, 10(1), 32-39. https://doi.org/ 10.20885/ ejem.vol10.iss1.art4

van der Wiele, T., Boselie, P., \& Hesselink, M. (2002). Empirical evidence for the relationship between customer satisfaction and business performance. Managing Service Quality: An International Journal, 12(3), 184-193. https://doi.org/10.1108/09604520210429259 Vieira, I., Rodrigues, A., Fernandes, D., \& Pires, C. (2016). The Role of Local Government Management of Tourism in Fostering Residents' Support to Sustainable Tourism Development: Evidence from a Portuguese Historic Town. International Journal of Tourism Policy, 6(2), 109-135.

Wahyuni, A., \& Utara, R. (2018). Pengaruh Penerimaan Pajak Hotel dan Pajak Restoran Terhadap Pendapatan Asli Daerah (PAD) pada Badan Pengelolaan Pajak dan Retribusi Daerah Kota Medan. Ekonomikawan: Jurnal Ilmu Ekonomi Dan Studi Pembangunan, 18(1), $1-11$.

Walters, R. G. (1991). Assessing the Impact of Retail Price Promotions on Product Substitution, Complementary Purchase, and Interstore Sales Displacement. Journal of Marketing, 55(2), 17-28. https://doi.org/10.1177/002224299105500203

White, G. I., Sondhi, A. C., \& Fried, D. (2003). The Analysis and Use of Financial Statements. Wiley.

Witt, S. F., Brooke, M. Z., Buckley, P. J., Brooke, M. Z., \& Buckley, P. J. (2013). The Management of International Tourism (RLE Tourism). Routledge. https://doi.org/ $10.4324 / 9780203068519$

$\mathrm{Wu}$, T.-P., \& Wu, H.-C. (2019). Tourism and economic growth in Asia: A bootstrap multivariate panel Granger causality. International Journal of Tourism Research, 21(1), 87-96. https://doi.org/10.1002/jtr.2243 
